J. Gen. Appl. Microbiol.

Vol. 11, No. 3, 1965

\title{
NEW SPECIES OF THE GENUS CANDIDA ISOLATED FROM FROZEN FOODS
}

\author{
KAZUO KOMAGATA and TAKASHI NAKASE \\ Central Research Laboratories, Ajinomoto Co., Inc., Kawasaki, Japan \\ Received October 27, 1965
}

In a previous paper (1), a number of yeasts found in frozen foods were reported; the numbers were more than $8 \%$ of the total microorganisms isolated. The yeasts isolated included Debaryomyces kloeckeri, Sporobolomyces roseus, Cryptococcus laurentii, Crypt. albidus, Crypt. luteolus, Torulopsis candida, Candida tropicalis, Cand. guilliermondii, Cand. zeylanoides, Cand. lipolytica, Cand. curvata, Cand. curiosa nov. sp., Cand. punicea nov. sp., Cand. salmonicola nov. sp., Cand. glaebosa nov. sp., Trichosporon pullulans, Trich. cutaneum, Rhodotorula glutinis, Rh. infirmo-miniata and Aureobasidium pullulans. This paper describes new species of Candida which grow at low temperatures. Others will be reported elsewhere.

\section{MATERIALS AND METHODS}

Yeasts were isolated from frozen foods by incubation at $0^{\circ}$ using the agar plate method. Two kinds of media were used: One (medium T) was composed of 1\% Tryptone (Difco), 1\% yeast extract (Difco), 0.5\% malt extract (Difco) and 2\% agar ( $\mathrm{pH}$ 7.2); the other was YM agar (Difco). Determinative methods were mainly those of Wickerham (2) and LodDer and KREGER-VAN RIJ (3). Temperature relations were determined by testing growth in liquid cultures at various temperatures including $-2^{\circ}, 4^{\circ}, 10^{\circ}$, $15^{\circ}, 17^{\circ}, 20^{\circ}, 22^{\circ}, 23^{\circ}, 24^{\circ}, 25^{\circ}, 30^{\circ}, 37^{\circ}$ and $42^{\circ}$. Growth was ascertained as follows: Incubated culture tubes were shaken, then placed against a white card on which two lines of $1 \mathrm{~mm}$ width and three lines of $0.2 \mathrm{~mm}$ width, $1.5 \mathrm{~mm}$ apart, were drawn with India ink, as illustrated in Fig. 1. When all the lines could not be seen through the growth, it was recorded as (HI) ; when thick lines were faintly visible and fine lines were obliterated, it was recorded as (t+t); when the fine lines appeared as an indistinct band, it was recorded as (it); when the fine lines could be distinguished but the edges of lines were indistinct, it was recorded as $(t)$; and when the edges could be distinctly seen, it was recorded as negative. Growth was observed every day for 2 weeks. Yeast nitrogen base (Difco) containing $1 \%$ glucose was employed. Lipolytic activity was tested by the method reported by Sierra (4) with a modified medium composed of $0.3 \%$ yeast extract (Difco), $0.5 \%$ peptone (Difco), $0.01 \% \mathrm{CaCl}_{2} \cdot 2 \mathrm{H}_{2} \mathrm{O}, 1 \% \mathrm{Tween}$, and $2 \%$ agar ( $\mathrm{pH} 7.0$ ). Tween 40, 60 and 80 were used as substrates, respectively. 


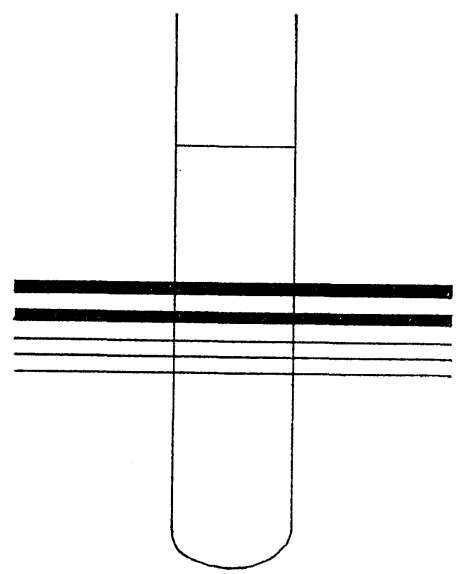

Fig. 1. Standard lines for record of growth

\section{RESULTS AND DISCUSSION}

1. Candida curiosa Komagata et Nakase nov. sp.

Strain: $\mathrm{P}-6$ and $\mathrm{P}-13$

In musto maltato cellulae subovoideae aut ovoideae, $(2.5-6.5) \times(3-9) \mu$, singulae aut binae. Sedimentum formatur. Cultura in agaro maltato (post unum mensem, $10^{\circ}$ ) flavo-albida, acclivis, mucosa, glabra aut crispulata, margine glabra aut piloso. Mycelium et pseudomycelium formantur. D-Glucosum et saccharosum fermentantur at non D-galactosum, maltosum, lactosum, trehalosum, raffinosum, melibiosum, cellobiosum, melezitosum, inulinum nec amylum. In medio minerali D-glucosum, D-galactosum, saccharosum, L-sorbosum, cellobiosum, trehalosum, raffinosum, inulinum, amylum (lente), D-xylosum (lente), L-arabinosum (aut lente), D-arabinosum (lente), D-ribosum (lente et exiguum), ethanolum (lente et exiguum), glycerolum (lente et exiguum), adonitolum, D-mannitolum, D-sorbitolum, acidum gluconicum, acidum 2-ketogluconicum, acidum succinicum (lente et exiguum), acidum citricum (lente et exiguum) et D-glucosaminicum hydrochloricum assimilantur at non maltosum, lactosum, melibiosum, melezitosum, L-rhamnosum, erythritolum, dulcitolum, $\alpha$-methyl-D-glucosidum, salicinum, acidum DL-lacticum, inositolum, acidum pyruvicum nec acetoacetatum aethylicum. Nitras kalicus assimilatur. Arbutinum non finditur. Vitaminae externae necessariae ad crescentiam. Maxima temperatura crescentiar: $22^{\circ}$. Isolata ex glaciali Sillago japonica, Kawasaki, Japan, 1963.

Growth in malt extract: After 3 days at $15^{\circ}$ cells are short oval to oval, $(2.5-6.5) \times(3-9) \mu$, and occur singly or in pairs. Occasionally septate cells are observed. Only a sediment is formed. After one month at $10^{\circ}$ a ring is also found. 
Growth on malt agar: After 3 days at $15^{\circ}$ cells are oval, $(2.5-7.5) \times$ $(4-11) \mu$, and occur singly or in pairs. After one month at $10^{\circ}$ the streak culture is yellowish white to light brownish gray, raised, dull, mucoid, and smooth or wrinkled. The margin is entire and occasionally surrounded by mycelia.

Dalmau plate culture on potato dextrose agar: Pseudo- and true mycelia abundantly develop and often ramify. Blastospores are short oval to oval and occur singly, in chains or in verticils.

Sporulation: No spores are observed.

Fermentation: D-Glucose and saccharose are fermented but D-galactose, maltose, lactose, trehalose, raffinose, melibiose, cellobiose, melezitose, inulin and soluble starch are not fermented.

Assimilation of carbon compounds: D-Glucose, D-galactose, saccharose, L-sorbose, cellobiose, trehalose, raffinose, inulin, adonitol, D-mannitol, D-sorbitol, gluconate, 2-ketogluconate and D-glucosamine hydrochloride are assimilated. D-Xylose, L-arabinose, D-arabinose and soluble starch are utilized latently, and D-ribose, ethanol, glycerol, succinate and citrate are latently and weakly assimilated. Maltose, lactose, melibiose, melezitose, L-rhamnose, erythritol, dulcitol, inositol, $\alpha$-methyl-D-glucoside, salicin, DL-lactate, pyruvate and ethyl acetoacetate are not utilized.

Potassium nitrate is utilized as the sole nitrogen source.

Arbutin is not splitted.

No growth occurs in vitamin-free medium.

No growth occurs in moderate osmotic pressure medium.

Maximum growth temperature is $22^{\circ}$.

Gelatin is liquefied.

Milk is peptonized.

Starch-like compounds are produced.

Lipolytic activities are observed for Tween 40,60 and 80.

Source: Frozen Sillago japonica, Kawasaki, Japan, 1963.

The isolates grow well between $4^{\circ}$ and $17^{\circ}$, moderately at $20^{\circ}$, poorly at $22^{\circ}$, but not at $23^{\circ}$. Good growth was still observed at $-2^{\circ}$ after a short lag period. As the optimum growth temperature of these yeasts is between $10^{\circ}$ and $17^{\circ}$, Candida curiosa is included in the category of strictly psychrophilic yeast according to the terminology of STokes (5). Relation to temperature is shown in Table. 1. The present species differs from Cand. scottii, a well-known psychrophilic species of Candida, in many respects, such as fermentation of sugars, formation of true mycelia, etc. LAWRENCE, Wilson and Pederson (6) reported a psychrophilic Candida isolated from grape juice but a precise comparison could not be made because a description was not given. This yeast ferments sugars and produces starch-like compounds. Torulopsis capsuligenes $(\boldsymbol{y})$ is the only species reported which possesses both the abilities of fermentation of sugars and production of starch-like compounds. Cand. curiosa also occasionally forms 

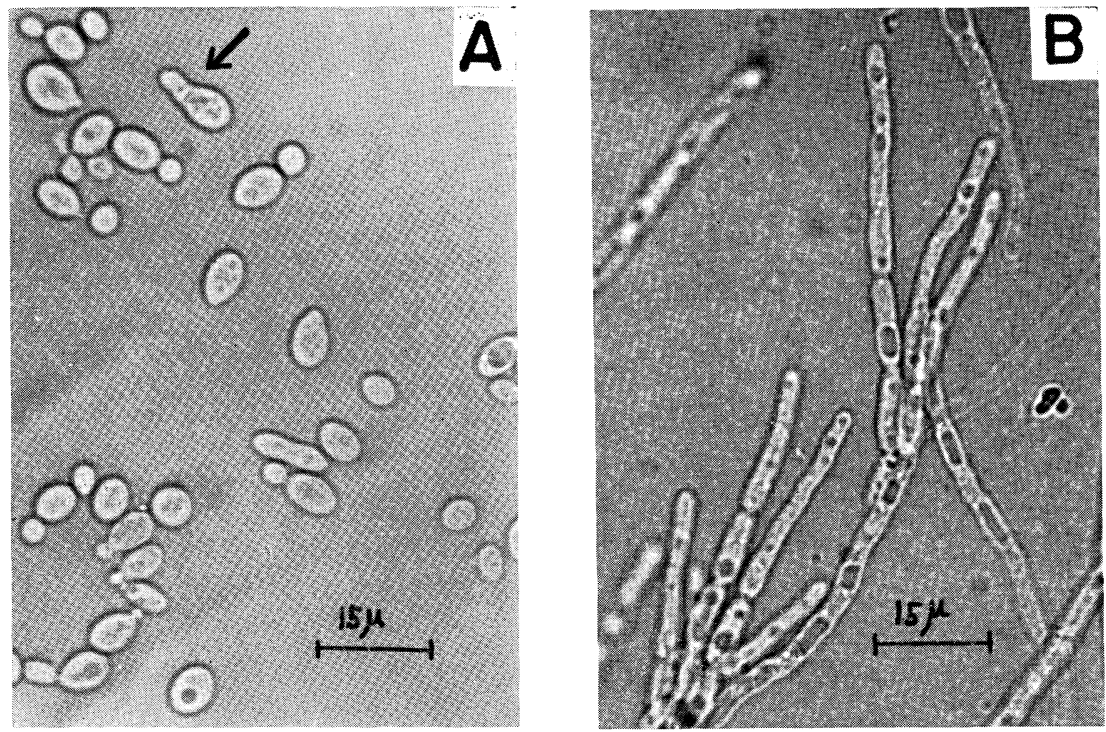

Fig. 2. Cells and true mycelia of Candida curiosa P-6

A. Cells of Cand. curiosa grown in malt extract for 3 days at $15^{\circ}$. Arrow indicates septate cell.

B. True mycelia of Cand. curiosa, Dalmau plate culture on potato dextrose agar (Difco) for 7 days at $10^{\circ}$.

Table 1. Growth of Candida curiosa P-6 at various temperatures

\begin{tabular}{|c|c|c|c|c|c|c|c|c|}
\hline \multirow{2}{*}{$\begin{array}{c}\text { Time } \\
\text { (days) }\end{array}$} & \multicolumn{8}{|c|}{ Temperature $\left({ }^{\circ} \mathrm{C}\right)$} \\
\hline & -2 & 4 & 10 & 15 & 17 & 20 & 22 & 23 \\
\hline 1 & - & + & + & + & + & + & - & - \\
\hline 2 & - & $H$ & \# & HI & $H$ & + & + & - \\
\hline 3 & $H$ & H & Ht & Ht & H & $H$ & + & - \\
\hline 4 & H & HH & HII & H & Ht & $H$ & + & - \\
\hline 5 & H & HW & WH & H & H & $H$ & + & - \\
\hline 6 & H & HI & 曲 & WI & HW & $H$ & + & - \\
\hline 7 & 册 & HII & 册 & WH & HI & $H$ & + & - \\
\hline 8 & HI & \# & HW & WI & 世 & $H$ & + & - \\
\hline 10 & HI & HiH & HI & HI & H & $H$ & $H$ & - \\
\hline 12 & 世1 & HI & 世1 & \# & 册 & $H$ & $H$ & - \\
\hline 14 & HI & WI & WI & WI & WI & H & H & - \\
\hline 16 & H & H & 册 & 册 & HI & H & $H$ & - \\
\hline
\end{tabular}


septate cells. The specific epithet is derived from Latin "curiosus" meaning "curious".

2. Candida punicea Komagata et Nakase nov. sp.

Strain: P-12

In musto maltato cellulae rotundae, subovoideae, ovoideae, tomaculiformes aut citriformes, $(3-8.5) \times(4.5-20) \mu$, singulae aut binae. Sedimentum formatur. Cultura in agaro maltato (post unum mensem, $10^{\circ}$ ) punicea aut subpunicea, elevata, glabra, parum nitida, mollis, margine glabra. Pseudomycelium et mycelium formantur. Fermentatio nulla. In medio minerali D-glucosum, saccharosum, maltosum, L-sorbosum, cellobiosum, trehalosum, raffinosum, melezitosum, inulinum (lente et exiguum), amylum, L-arabinosum, D-arabinosum (lente), D-ribosum, L-rhamnosum (lente et exiguum), ethanolum (lente), glycerolum, adonitolum, dulcitolum (lente), D-mannitolum, D-sorbitolum, acidum gluconicum, acidum 2-ketogluconicum, acidum succinicum (exiguum) acidum citricum (lente et exiguum) et inositolum (lente et exiguum) assimilantur at non D-galactosum, lactosum, melibiosum, D-xylosum, erythritolum, $\alpha$-methyl-D-glucosidum, salicinum, acidum DL-lacticum, D-glucosaminicum hydrochloricum, acidum pyruvicum nec acetoacetatum aethylicum. Nitras kalicus assimilatur. Arbutinum finditur. Vitaminae externae necessariae ad crescentiam. Maxima temperatura crescentiar: $23^{\circ}$. Isolata ex glaciali salmone, Kawasaki, Japan, 1963.

Growth in malt extract: After 3 days at $17^{\circ}$ cells are round (rare), short oval to oval, sausage-shaped or sometimes lemon-shaped, $(3-8.5) \times$ $(4.5-20) \mu$, and occur singly or in pairs. Only a sediment is formed. After one month at $10^{\circ}$ a ring is also found.

Growth on malt agar: After 3 days at $17^{\circ}$ cells are oval to long oval, sometimes sausage-shaped, $(2.5-8) \times(4.5-17.5) \mu$, and occur singly or in pairs. After one month at $10^{\circ}$ the streak culture is pale pink to pink, raised, smooth, slightly shining, soft and has an entire margin.

Dalmau plate culture on nitrogen deficient agar: After 3 weeks at $10^{\circ}$ pseudo- and true mycelia develop rather primitively. Pseudomycelia consist of oval to long oval cells and often ramify. No significant difference is observed between blastospores and pseudomycelial cells. True mycelia are usually primitive, but sometimes develop fairly well. True mycelial cells are often curved and septate.

Sporulation: No spores are observed.

Fermentation: No sugars are fermented.

Assimilation of carbon compounds: D-Glucose, saccharose, maltose, L-sorbose, cellobiose, trehalose, raffinose, melezitose, soluble starch, L-arabinose, D-ribose, glycerol, adonitol, D-mannitol, D-sorbitol, gluconate and 2-ketogluconate are assimilated. D-Arabinose, ethanol and dulcitol are latently assimilated. Succinate is utilized weakly. Inulin, L-rhamnose, citrate and inositol are assimilated latently and weakly. D-Galactose, lactose, melibiose, D-xylose, erythritol, $\alpha$-methyl-D-glucoside, salicin, DL- 
lactate, D-glucosamine hydrochloride, pyruvate and ethyl acetoacetate are not assimilated.

Potassium nitrate is utilized as the sole nitrogen source.

Arbutin is splitted.

No growth occurs in vitamin-free medium.

No growth occurs in moderate osmotic pressure medium.

Maximum growth temperature is $23^{\circ}$.

Gelatin is liquefied.

Milk is peptonized.

Starch-like compounds are produced.

Lipolytic activities are observed for Tween 40,60 and 80 .

Source: Frozen salmon-stick, Kawasaki, Japan, 1963.

The isolate assimilates D-glucose, saccharose, maltose and potassium nitrate but does not ferment sugars. These properties are similar to those of Cand. melinii. The isolate forms larger cells than Cand. melinii does, and does not form pseudomycelia on ordinary media but only after a long period of cultivation on nitrogen-deficient media such as Yeast Carbon Base (Difco) containing 2\% agar, forms primitive pseudo- and true mycelia. Cand. melinii forms abundant pseudomycelia but not true mycelia. Furthermore, the isolate, in contrast with Cand. melinii, produces starchlike compounds in adequate conditions. This yeast grows well between $15^{\circ}$ and $20^{\circ}$, moderately at $22^{\circ}$, scanty at $23^{\circ}$ but not at $24^{\circ}$. Fairly good growth is still observed at $-2^{\circ}$ after about one week lag period. Relation to temperature is shown in Table 2. This species is also considered to be a strictly psychrophilic yeast. The specific epithet is derived from Latin "puniceus" meaning "pinkish-colored".

3. Candida salmonicola Komagata et Nakase nov. sp.

Strain: P-32

In musto maltato cellulae rotundae aut subovoideae, $(2-8) \times(2-8) \mu$, singulae aut binae. Sedimentum formatur. Cultura in agaro maltato (post unum mensem, $17^{\circ}$ ) flavo-glauca, plana aut elevata, glabra, mollis, margine glabra. Pseudomycelium et mycelium formantur. D-Glucosum, saccharosum (exiguum), maltosum et trehalosum (lente et exiguum) fermentantur at non D-galactosum, lactosum, raffinosum, melibiosum, melezitosum, inulinum nec amylum. In medio minerali D-glucosum, D-galactosum, saccharosum, maltosum, L-sorbosum, trehalosum, melezitosum, D-xylosum, ethanolum, glycerolum, adonitolum, D-mannitolum, D-sorbitolum, $\alpha$-methyl-D-glucosidum, salicinum, acidum gluconicum, acidum 2-ketogluconicum, acidum DL-lacticum (lente), acidum succinicum, acidum pyruvicum et D-glucosaminicum hydrochloricum assimilantur at non lactosum, cellobiosum, melibiosum, raffinosum, inulinum, amylum, L-arabinosum, D-arabinosum, D-ribosum, L-rhamnosum, erythritolum, dulcitolum, acidum citricum, inositolum nec acetoacetatum aethylicum Nitras kalicus non assimilatur. Arbutinum finditur. Vitaminae externae non necessariae ad crescentiam. Isolata ex glaciali salmone, 

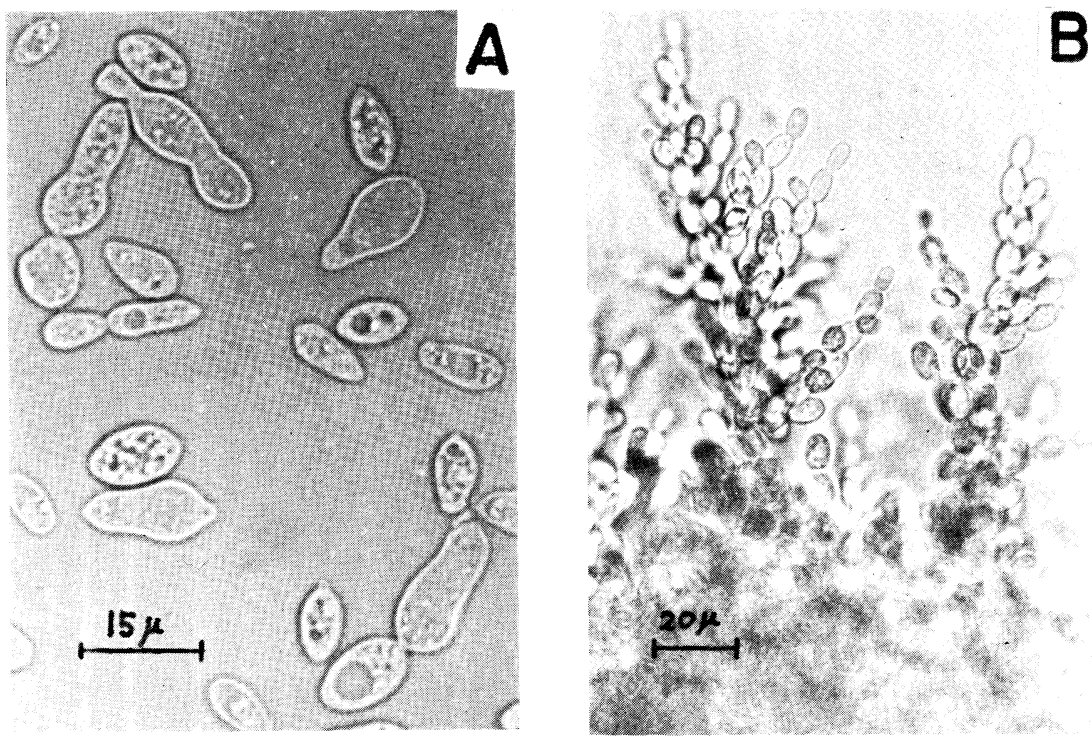

Fig. 3. Cells and pseudomycelia of Candida punicea P-12

A. Cells of Cand. punicea grown in malt extract for 3 days at $17^{\circ}$.

B. Pseudomycelia of Cand. punicea, Dalmau plate culture on yeast nitrogen base (Difco) containing 2\% agar for 3 weeks at $10^{\circ}$.

Table 2. Growth of Candida punicea $\mathrm{P}-12$ at various temperatures

\begin{tabular}{|c|c|c|c|c|c|c|c|c|c|}
\hline \multirow{2}{*}{$\begin{array}{l}\text { Time } \\
\text { (days) }\end{array}$} & \multicolumn{9}{|c|}{ Temperature $\left({ }^{\circ} \mathrm{C}\right)$} \\
\hline & -2 & 4 & 10 & 15 & 17 & 20 & 22 & 23 & 24 \\
\hline 1 & - & - & - & - & - & - & - & - & - \\
\hline 2 & - & + & + & + & $H$ & + & - & - & - \\
\hline 3 & + & + & $H$ & $H$ & $H$ & H & + & + & - \\
\hline 4 & + & $H$ & H & H & Ht & H & + & + & - \\
\hline 5 & + & $H$ & H & H & HH & HH & + & + & - \\
\hline 6 & H & $\mathrm{HH}$ & H & H & H & HH & $H$ & + & - \\
\hline 7 & $H$ & $H$ & H & HI & H & $\mathrm{HH}$ & $H$ & + & - \\
\hline 8 & $\mathrm{H}$ & $\mathrm{HH}$ & W & H & HH & H & $H$ & + & - \\
\hline 10 & H & HH & H & H & H & $\mathrm{H}$ & $H$ & + & - \\
\hline 12 & $H$ & $H$ & H & H & 册 & H & $H$ & + & - \\
\hline 14 & $\mathrm{Ht}$ & HI & WII & HWI & HIt & HWI & H & + & - \\
\hline 16 & WI & HII & HW & HW & WIt & HWH & $H$ & + & - \\
\hline
\end{tabular}


Kawasaki, Japan, 1963.

Growth in malt extract: After 3 days at $15^{\circ}$ cells are round (predominant) or short oval, $(2-8) \times(2-8) \mu$, and occur singly or in pairs. Only a sediment is formed. After one month at $10^{\circ}$ an incomplete pellicle is also observed.

Growth on malt agar: After 3 days at $15^{\circ}$ cells are round (predominant) or short oval to oval, $(2-5) \times(2-8) \mu$, and occur singly or in pairs. After one month at $10^{\circ}$ the streak culture is yellowish gray, flat to raised, smooth, soft, dull shining, and has an entire margin.

Slide culture on potato dextrose agar: Pseudo- and true mycelia develop abundantly. They are much ramified. Blastospores are round to long oval.

Sporulation: No spores are observed.

Fermentation: D-Glucose and maltose are fermented. Saccharose is weakly fermented and trehalose weakly and latently. D-Galactose, lactose, raffinose, melibiose, melezitose, inulin and soluble starch are not fermented.

Assimilation of carbon compounds: D-Glucose, D-galactose, saccharose, maltose, L-sorbose, trehalose, melezitose, D-xylose, ethanol, glycerol, adonitol, D-mannitol, D-sorbitol, $\alpha$-methyl-D-glucoside, salicin, gluconate, 2-ketogluconate, succinate, D-glucosamine hydrochloride and pyruvate are assimilated. DL-Lactate is utilized latently. Lactose, cellobiose, melibiose, raffinose, inulin, soluble starch, L-arabinose, D-arabinose, D-ribose, L-rhamnose, erythritol, dulcitol, citrate, inositol and ethyl acetoacetate are not assimilated.

Potassium nitrate is not utilized as the sole nitrogen source.

Arbutin is splitted.

Good growth occurs in vitamin-free medium.

Good growth occurs in moderate osmotic pressure medium.

No growth occurs at $30^{\circ}$.

Gelatin is not liquefied.

Milk is not peptonized.

Starch-like compounds are not produced.

Lipolytic activities are not observed for Tween 40,60 and 80.

Source: Frozen salmon-stick, Kawasaki, Japan, 1963.

The isolate forms well developed pseudo- and true mycelia and is similar to Cand. viswanathii $(8,9)$. But Cand. salmonicola does not form hairy projections on streak culture which is a distinguishing character of Cand. viswanathii. Moreover, the isolate does not ferment D-galactose, fails to assimilate cellobiose, D-ribose and citrate, and grow well between $10^{\circ}$ and $25^{\circ}$, and fairly well at $-2^{\circ}$ after a short lag period but does not grow at $37^{\circ}$. Relation to temperature is shown in Table 3. On the contrary, Cand. viswanathii ferments D-galactose, assimilates the compounds mentioned above and exhibits good growth at $37^{\circ}$. The specific epithet is derived from Latin "salmo" meaning "salmon" and "colo" meaning "inhabit".

4. Candida glaebosa Komagata et Nakase nov. sp.

Strain: P-40 

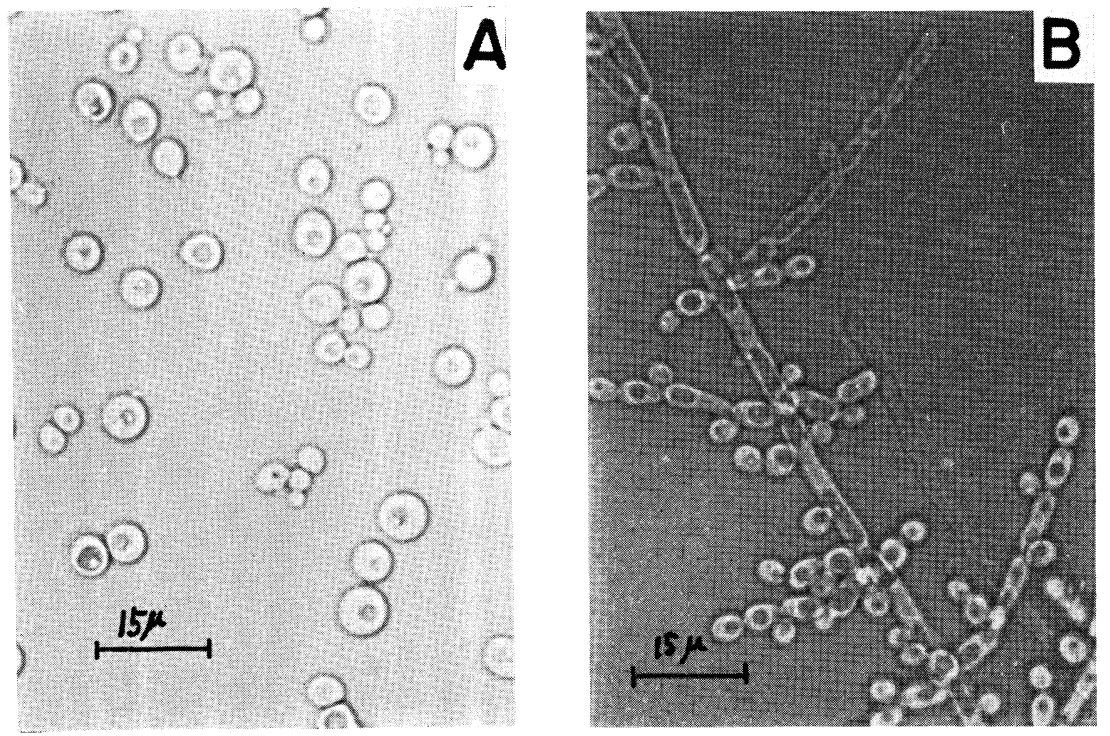

Fig. 4. Cells and pseudomycelia of Candida salmonicola P-32

A. Cells of Cand. salmonicola grown in malt extract for 3 days at $15^{\circ}$.

B. Pseudomycelia of Cand. salmonicola, slide culture on potato dextrose agar (Difco) for 7 days at $25^{\circ}$.

Table 3. Growth of Candida salmonicola P-32 at various temperatures

\begin{tabular}{|c|c|c|c|c|c|c|c|c|}
\hline \multirow{2}{*}{$\begin{array}{l}\text { Time } \\
\text { (days) }\end{array}$} & \multicolumn{8}{|c|}{ Temperature $\left({ }^{\circ} \mathrm{C}\right)$} \\
\hline & -2 & 4 & 10 & 15 & 17 & 20 & 25 & 30 \\
\hline 1 & + & + & $H$ & m & H & H & Ht & - \\
\hline 2 & + & Ht & Ht & HI & H & HI & H & - \\
\hline 3 & + & Ht & HIt & HI & HIt & HII & HI & - \\
\hline 4 & H & 冊 & HII & HI & HIt & 冊 & H1 & - \\
\hline 5 & H & 册 & HII & HII & 曲 & HI & 冊 & - \\
\hline 6 & HII & H & HWH & HH & HI & 册 & HIt & - \\
\hline 7 & WH & HII & WH & HIt & 册 & HI & WI & - \\
\hline 8 & 册 & HI & 册 & HH & HIt & HI & HI & - \\
\hline 10 & HW & HII & HWH & HI & $\mathrm{HH}$ & HII & 曲 & - \\
\hline 12 & $H H$ & HW & HI & 曲 & WH & HIt & HI & - \\
\hline 14 & HII & HII & HII & HII & 册 & WH & HIt & - \\
\hline 16 & 曲 & 冊 & 曲 & HW & 册 & 曲 & WI & - \\
\hline
\end{tabular}


In musto maltato cellulae minuta, subovoideae aut ovoideae, $(1.5-4) \times$ $(2.5-4.5) \mu$, interdum cellulae magnae, $5.5 \times 10 \mu$. Glebae minutae formantur. Sedimentum et pellicula formantur. Cultura in agaro maltato (post unum mensem, $10^{\circ}$ ) albida, elevata, sicca, squamea, crispulata, glaebosa, margine glabra. Pseudomycelium formatur. Fermentatio nulla. In medio minerali D-glucosum, D-galactosum, saccharosum, maltosum, lactosum, L-sorbosum (lente), cellobiosum, trehalosum, melibiosum, raffinosum, D-xylosum, Darabinosum (lente), ethanolum, glycerolum, adonitolum, D-mannitolum, D-sorbitolum, $\alpha$-methyl-D-glucosidum, salicinum, acidum gluconicum (lente), acidum 2-ketogluconicum, acidum DL-lacticum, acidum succinicum (exiguum), acidum citricum (lente), D-glucosaminicum hydrochloricum, acidum pyruvicum et acetoacetatum aethylicum (lente) assimilantur at non melezitosum, inulinum, amylum, L-arabinosum, D-ribosum, L-rhamnosum, erythritolum, dulcitolum nec inositolum. Nitras kalicus non assimilatur. Arbutinum finditur. Vitaminae externae necessariae ad crescentiam. Isolata ex glaciali loligene, Kawasaki, Japan, 1963.

Growth in malt extract: After 3 days at $25^{\circ}$ cells are small, short oval to oval, $(1.5-4) \times(2.5-4.5) \mu$; sometimes larger cells are present which measure up to $5.5 \times 10 \mu$. Most cells agglutinate tightly to form small lumps and can not be dispersed easily. A dry, white and fragile pellicle and a granular sediment are formed. After one month at $10^{\circ}$ a pellicle and a sediment are present.

Growth on malt agar: After 3 days at $25^{\circ}$ cells are oval, $(2-3.5) \times$ $(3-7.5) \mu$. Most cells agglutinate tightly to form small lumps as seen in malt extract. After one month at $10^{\circ}$ the streak culture is white, raised, dry, flaky, delicately wrinkled and lumpish. The margin is entire to undulate.

Slide culture on potato dextrose agar: Ramified pseudomycelia are observed but restricted. Blastospores are round to oval and occur singly or in chains.

Sporulation: No spores are observed.

Fermentation: No sugars are fermented.

Assimilation of carbon compounds: D-Glucose, D-galactose, saccharose, maltose, lactose, cellobiose, trehalose, melibiose, raffinose, D-xylose, ethanol, glycerol, adonitol, D-mannitol, D-sorbitol, $\alpha$-methy-D-glucoside, salicin, 2-ketogluconate, DL-lactate, D-glucosamine hydrochloride and pyruvate are assimilated. L-Sorbose, D-arabinose, gluconate, citrate and ethyl acetoacetate are latently utilized. Succinate is weakly assimilated. Melezitose, inulin, soluble starch, L-arabinose, D-ribose, L-rhamnose, erythritol, dulcitol and inositol are not assimilated.

Potassium nitrate is not utilized as the sole nitrogen source.

Arbutin is splitted.

No growth occurs in vitamin-free medium.

Moderate growth occurs in moderate osmotic pressure medium. 

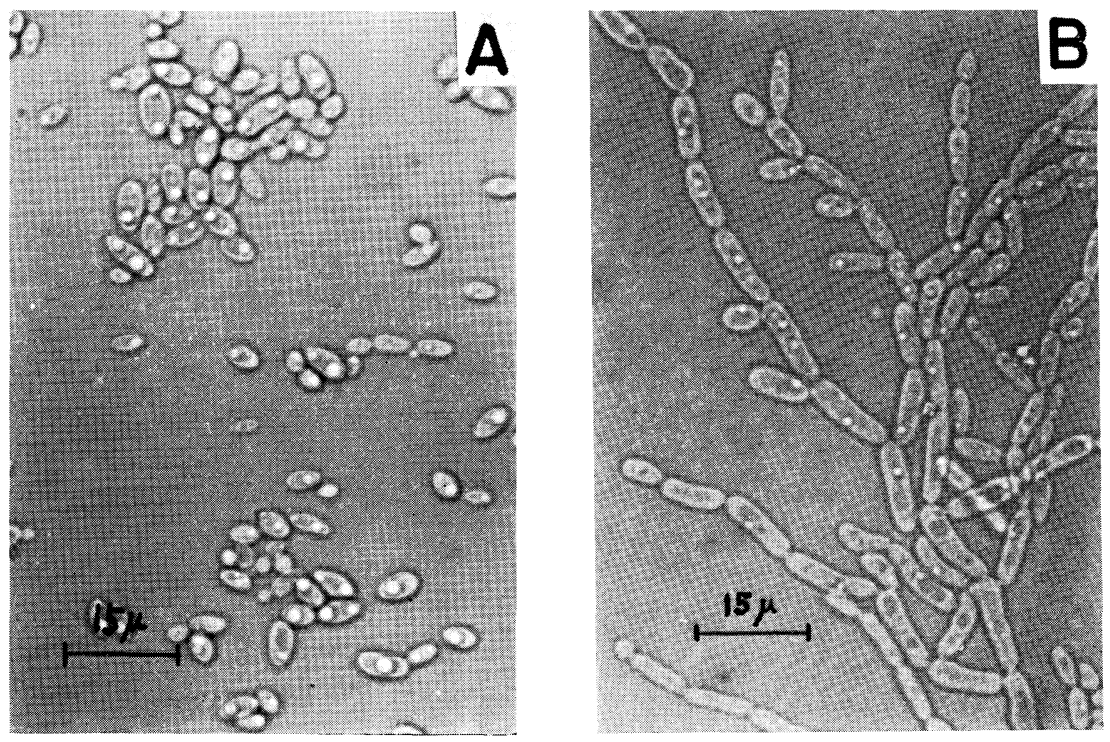

Fig. 5. Cells and pseudomycelia of Candida glaebosa P-40

A. Cells of Cand. glaebosa grown in malt extract for 3 days at $25^{\circ}$.

B. Pseudomycelia of Cand. glaebosa slide culture on potato dextrose agar (Difco) for 7 days at $25^{\circ}$.

Table 4. Growth of Candida glaebosa $\mathrm{P}-40$ at various temperatures

\begin{tabular}{|c|c|c|c|c|c|c|c|c|c|}
\hline \multirow{2}{*}{$\begin{array}{l}\text { Time } \\
\text { (days) }\end{array}$} & \multicolumn{9}{|c|}{ Temperature $\left({ }^{\circ} \mathrm{C}\right)$} \\
\hline & -2 & 4 & 10 & 15 & 17 & 20 & 25 & 30 & 37 \\
\hline 1 & - & - & - & - & - & - & + & - & - \\
\hline 2 & - & - & - & - & + & H & HI & + & - \\
\hline 3 & - & - & - & $H$ & H & HI & HH & + & - \\
\hline 4 & - & - & + & H & 册 & WH & m & $H$ & - \\
\hline 5 & - & - & + & H & WI & WI & H & H & - \\
\hline 6 & - & - & + & 册 & WH & WI & 曲 & $H$ & - \\
\hline 7 & - & - & $H$ & W & \# & 世 & 世l一 & H & - \\
\hline 8 & - & + & H & W & 世 & 曲 & m & H & - \\
\hline 10 & - & $H$ & WI & W & 世冊 & HI & WI & H & - \\
\hline 12 & + & $H$ & 册 & \#1 & m & \# & m & mW & - \\
\hline 14 & + & 曲 & 曲 & WH & mI & WH & Wll & WI & - \\
\hline 16 & + & WI & WI & 曲 & 曲 & WI & \#\# & HW & - \\
\hline
\end{tabular}


No growth occurs at $37^{\circ}$.

Gelatin is not liquefied.

Milk is not peptonized.

Starch-like compounds are not produced.

Lipolytic activities are not observed for Tween 40,60 and 80.

Source: Frozen cuttle-fish, Kawasaki, Japan, 1963.

The isolate assimilates D-glucose, D-galactose, saccharose, maltose and lactose but not potassium nitrate, and no fermentation of sugar is observed. These properties are similar to those of Cand. humicola, Cand. curvata and Cand. corniculata (10) but not identical and the cells of the former are smaller. Moreover, Cand. glaebosa never exhibits the shapes of long oval, elongated, slender, curved, lemon-shaped and spindle-shaped cells found in Cand. humicola; curved and long oval cells in Cand. curvata; or spindleshaped, sausage-shaped and triangular cells in Cand. corniculata. The isolate has a remarkable character to agglutinate tightly and to form small lumps which can not be dispersed easily, and the streak culture is dry, flaky and lumpish. This yeast grows well between $15^{\circ}$ and $25^{\circ}$, rather slowly at $10^{\circ}$ and $30^{\circ}$, and fairly well at $4^{\circ}$ after about 10 days lag period. Scanty growth is observed at $-2^{\circ}$ after about 2 week's cultivation. Relation to temperature is shown in Table 4. The specific epithet is derived from Latin "glaebosus" meaning "lumpy".

The authentic cultures, Cand. curiosa P-6, Cand. punicea P-12, Cand. salmonicola $\mathrm{P}-32$ and Cand. glaebosa $\mathrm{P}-40$, have been deposited with the Institute of Applied Microbiology, University of Tokyo (IAM), and Institute for Fermentation, Osaka (IFO).

\section{SUMMARY}

Of the yeasts isolated from frozen foods, the following four new species of Candida were identified: Cand. curiosa, Cand. punicea, Cand. salmonicola and Cand. glaebosa. Cand. curiosa and Cand. punicea are included in the category of strict psychrophiles.

The authors wish to thank Dr. N. Katsuya of this institute for his encouragement throughout this work.

\section{REFERENCES}

(1) K. Komagata, H. Ogawa and N. Katsuya: J. Food Hyg. Soc. Japan. 5, 441 (1964), in Japanese

(2) L. J. Wickerham: Taxonomy of yeasts, U. S. D. A. Tech. Bull. No. 1029 (1951)

(3) J. Lodder and N. J. W. KREger-VAN RIJ: The yeasts, a taxonomic study, North-Holland Pub. Co., Amsterdam (1952)

(4) G. Sierra: Antonie van Leeuwenhoek., 23, 15 (1957)

(5) J. L. Stokes: Recent Progress in Microbiology VIII, p. 187, Univ. of Toronto Press (1962) 
(6) N. L. Lawrence, D. C. Wilson and C. S. Pederson: Appl. Microbiol., 7, 7 (1959)

(7) J. P. VAN DER WALT and A. E. van Kerken: Antonie van Leeuwenhoek., 27, 206 (1961)

(8) R. Viswanathan and H. S. Randhawa: Science and Culture, 25, 86 (1959)

(9) R. S. Sandhu and H. S. Randhawa: Mycopathologia, 18, 179 (1962)

(10) H. Kuraishi: Sci. Rep. Tohoku Univ. IV, 24, 59 (1958) 